\title{
OCCURRENCE AND ULTRASTRUCTURAL CHARACTERIZATION OF "NUAGE" DURING OOGENESIS AND EARLY SPERMATOGENESIS OF Piaractus mesopotamicus HOLMBERG, 1887 (TELEOSTEI)
}

\author{
ABDALLA, F. C. and CRUZ-LANDIM, C. \\ Departamento de Biologia, Instituto de Biociências, Universidade Estadual Paulista (UNESP), Rio Claro, SP, Brazil \\ Correspondence to: Fábio Camargo Abdalla, Departamento de Biologia, Instituto de Biociências, Universidade \\ Estadual Paulista (UNESP), Av. 24 A, n. 1515, CEP 13506-900, Bela Vista, \\ Rio Claro, SP, Brazil, e-mail: fabdalla@rc.unesp.br
}

Received November 8, 2002 - Accepted March 27, 2003 - Distributed August 31, 2004

(With 3 figures)

\begin{abstract}
We investigated the occurrence and ultrastructurally characterized electrondense nuclear material (nuage) released from the nucleus during oogenesis and early spermatogenesis of Piaractus mesopotamicus, a fish from Pantanal Matogrossense (Brazil) having a seasonal reproductive cycle. The female germ cells presented two instances of nuclear material extrusion: in the oogonia and in the oocyte in the perinucleolar phase. In males, material with similar morphology and behavior occurred in the spematogonia. In all cases, this material was associated to mitochondria. The possible function of this material is discussed.
\end{abstract}

Key words: nuage, germ plasm, oogenesis, spermatogenesis, Piaractus mesopotamicus.

\section{RESUMO}

\section{Ocorrência e caracterização ultra-estrutural de "nuage" durante a ovogênese e o início da espermatogênese de Piractus mesopotamicus Holmberg, 1887 (Teleostei)}

Foi investigada a ocorrência e caracterizada ultra-estruturalmente a eliminação de material nuclear eletrondenso (nuage) para o citoplasma durante a ovogênese e durante os estágios iniciais da espermatogênese de Piaractus mesopotamicus, um peixe do Pantanal Matogrossense de ciclo reprodutivo sazonal. Constataram-se nas células germinativas femininas dois momentos de eliminação desse material, na ovogônia e no ovócito em fase perinucleolar. Nas células masculinas, material com morfologia e comportamento muito semelhante foi encontrado na espermatogônia. Em todos os casos, o material associou-se a mitocôndrias. A possível função desse material foi discutida.

Palavras-chave: nuage, plasma germinativo, ovogênese, espermatogênese, Piaractus mesopotamicus.

\section{INTRODUCTION}

Female fish, as do most vertebrates, suspend meiosis in diplotene (prophase of the first meiosis division) until ovulation. The chromosomes decondensate and a great amount of RNA is translated from some specific chromatin regions (Alberts et al., 1989). This RNA is condensed in numerous micronucleoli distributed close to the nuclear envelope inner face (Yamamoto, 1956; Cruz-Landim \&
Cruz-Höfling, 1979; Agostinho, 1985; Selman \& Wallace, 1983; Cruz-Höfling \& Cruz-Landim, 1990; Guimarães \& Quagio-Grassiotto, 2001, 2002). A large and vesicular nucleus, with an irregular nuclear envelope and numerous peripheric nucleoli is, therefore, characteristic of young pre-vitellogenic oocytes (Cruz-Höfling \& Cruz-Landim, 1990) in primary growth stage (Tyler \& Sumpter, 1996). In the primary growth stage, material is frequently found in the oocytes, similar to that of the nucleoli in the 
outer face of the nuclear envelope. This material seems to be transferred in its entirety to the cytoplasm (Lewis \& McMillan, 1965; Droller \& Roth, 1966; Eddy, 1975; Clérot, 1976, 1979; Cruz-Landim \& Cruz-Höfling, 1979; Guimarães \& Quagio-Grassiotto, 2001, 2002). Later, it associates with mitochondria and disperses in the cytoplasm at the beginning of vitellogenesis (Esper, 1965; Clérot, 1976, 1979; CruzLandim \& Cruz-Höfling, 1979; Cruz-Höfling \& CruzLandim, 1990). This material of nuclear origin has been called "nuage" and is found in gametes of many vertebrates (Eddy, 1975; Russel \& Frank, 1978). There are indications that oocyte nuage ultimately constitutes germ plasm which is responsible for the germ line specification during embryogenesis (Eddy, 1975; Esper, 1965; van Gansen \& Shram, 1968; CruzLandim \& Cruz-Höfling, 1979). This material is not very well characterized in fish oocytes, but there are few data on occurrence and behavior of similar material in the oogonia and spermatogonia, and on its final destiny and significance (Cruz-Landim \& Cruz-Höfling, 1979; Selman \& Wallace, 1983; Guimarães \& Quagio-Grassiotto, 2001, 2002; Abdalla \& Cruz-Landim, 2003).

The aim of the present investigation is to characterize the presence of nuage during oogenesis and early spermatogenesis of $P$. mesopotamicus, a fish from Pantanal Matogrossense (Brazil) having a seasonal reproductive cycle, in order to contribute to the knowledge of the behavior of the nucleuscytoplasm exchanges during gametogenesis.

\section{MATERIAL AND METHODS}

In Pantanal Matogrossense (State of Mato Grosso do Sul, Brazil), female and male specimens of Piaractus mesopotamicus (Teleostei) were collected in feeding and breeding sites at the Aquidauana and Miranda rivers during the months of April and September. Ovary and testis fragments were fixed in $2.5 \%$ gluraldehyde in $0.1 \mathrm{M}$ sodium cacodylate buffer, and then post-fixed in $1 \%$ osmium tetroxide in the same buffer. After a rinse in the buffer, the material was dehydrated in a standard acetone series (30\% to 100\%) and included in Epon 812 resin. Semi-thin sections were analyzed under a light microscope after being stained with methylene blue and azure II, as well as with toluidine blue. Ultrathin sections were contrasted with uranile acetate and lead citrate and then examined and photographed under a Zeiss EM9S2 transmission electron microscope (TEM).

\section{RESULTS AND DISCUSSION}

In the testes and ovaries of this species of fish, as in others, oogonia and spermatogonia are found alone, or in groups of two or three in the follicle wall (Dadzie, 1969; Shrestha \& Khanna, 1978; Grier, 1981; Romagosa, 1991; Romagosa et al., 1993, 2000). In our study, these germ cells usually were large with the nucleus occupying a considerable part of their volume, presenting in the cytoplasm many spherical mitochondria and very few endoplasmic reticulum profiles (Figs. 1A and 2A, B). The nuclear chromatin presented completely dispersed in such a way that the generally spherical and very electrondense nucleolus became very conspicuous (Figs. 1A and 2A). Various electrondense granules, intensely stained by toluidine blue, were found attached to the cytoplasmatic side of the nuclear envelope of these cells (Figs. 1A and 2A, B). This material, showing the same morphology and topology of previously described nuage, which occurs in several species (Kessel, 1968; Kato, 1968; Eddy, 1975; Clérot, 1976, 1979; CruzLandim \& Cruz-Höfling, 1979; Bruslé, 1980; Dohmen, 1985; Cruz-Höfling \& Cruz-Landim, 1990; Reunov et al., 2000). In the spermatogonia, the nuclear envelope frequently presented a pronounced depression, where the nuage lodged (Fig. 2B). When this material detached from the nuclear envelope, it formed dense granules that associated with groups of mitochondria in oogonia (Fig. 1A) as well as in spermatogonia (Fig. 2B). This association has been observed in other species of fishes (Grier, 1981; Bruslé, 1980; Silva, 1987). The material transferred from the nucleus was similar in both sexes in morphology, staining qualities, and association with mitochondria. The mitochondria were poor in cristae and presented diverse sizes (Figs. 1A and 2B).

As this material stained, it showed morphology and electrondensity characteristics similar to the nucleolar material (Figs. 1A and 2A). We suggest that it is constituted by ribonucleoproteins. 

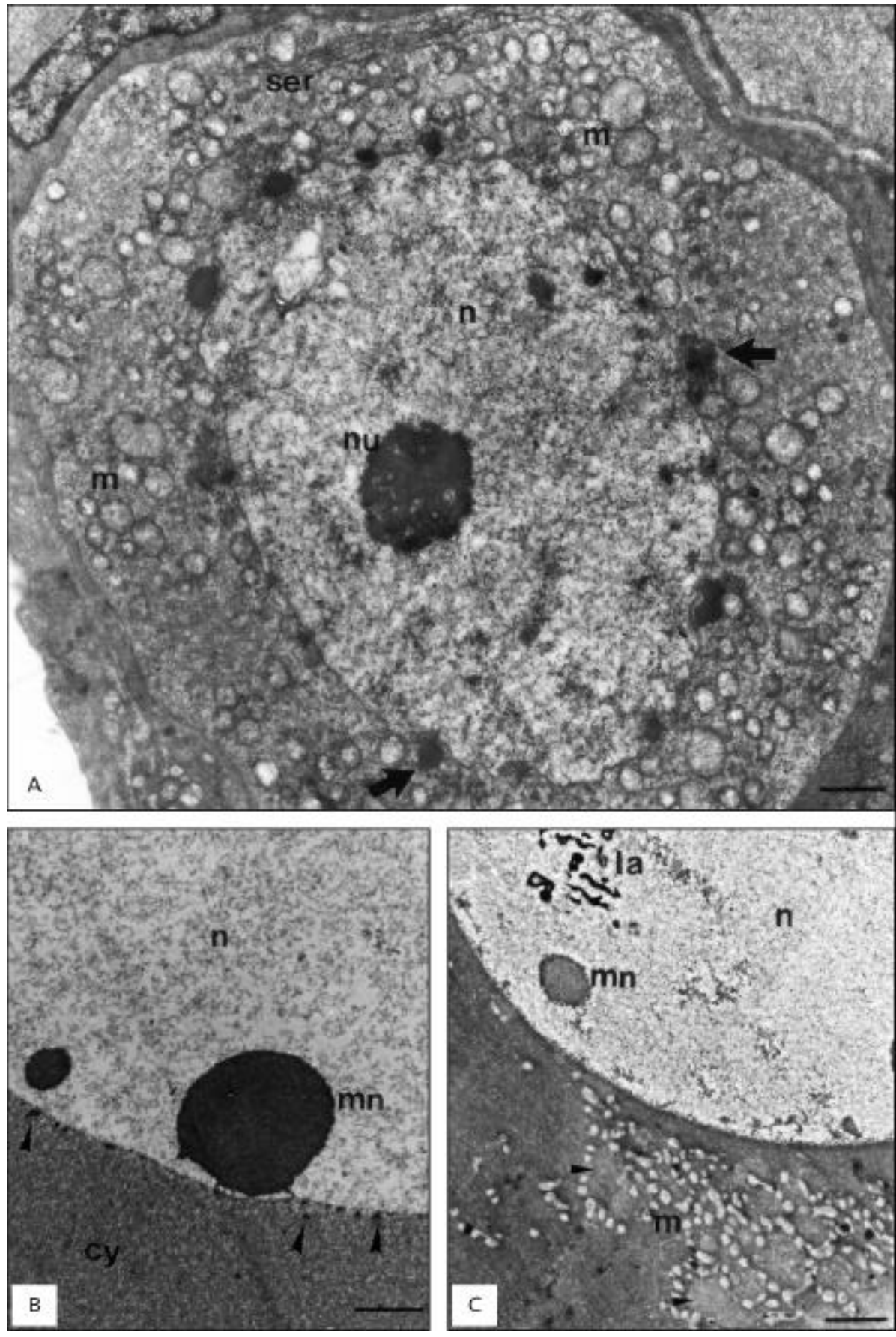

Fig. 1 - A. Transmission electron micrograph (TEM) of an oogonium, showing the large nucleus (n) with a prominent nucleolus (nu). Notice electrondense material (arrows) in the cytoplasmic side of the nuclear envelope, which may be associated with spherical mitochondria $(\mathrm{m})$. ser, smooth endoplasmic reticule; Bars $=2 \mu \mathrm{m}$. B. Detail of the nuclear region of a perinucleolar oocyte. Notice in the nucleus (n) a micronucleolus (mn) and nuage (arrow's head) associated with the cytoplasmic face of the nuclear envelope and the nucleolar material going towards the nuclear envelope. cy, oocyte cytoplasm; Bars $=3 \mu \mathrm{m}$. C. Perinuclear region of an oocyte's cytoplasm, showing nuage (arrowhead) associated with mitochondria (m). Notice in the nucleus (n) lamellar structures (la). $\mathrm{mn}=$ micronucleolus; $\operatorname{Bars}=3 \mu \mathrm{m}$. 

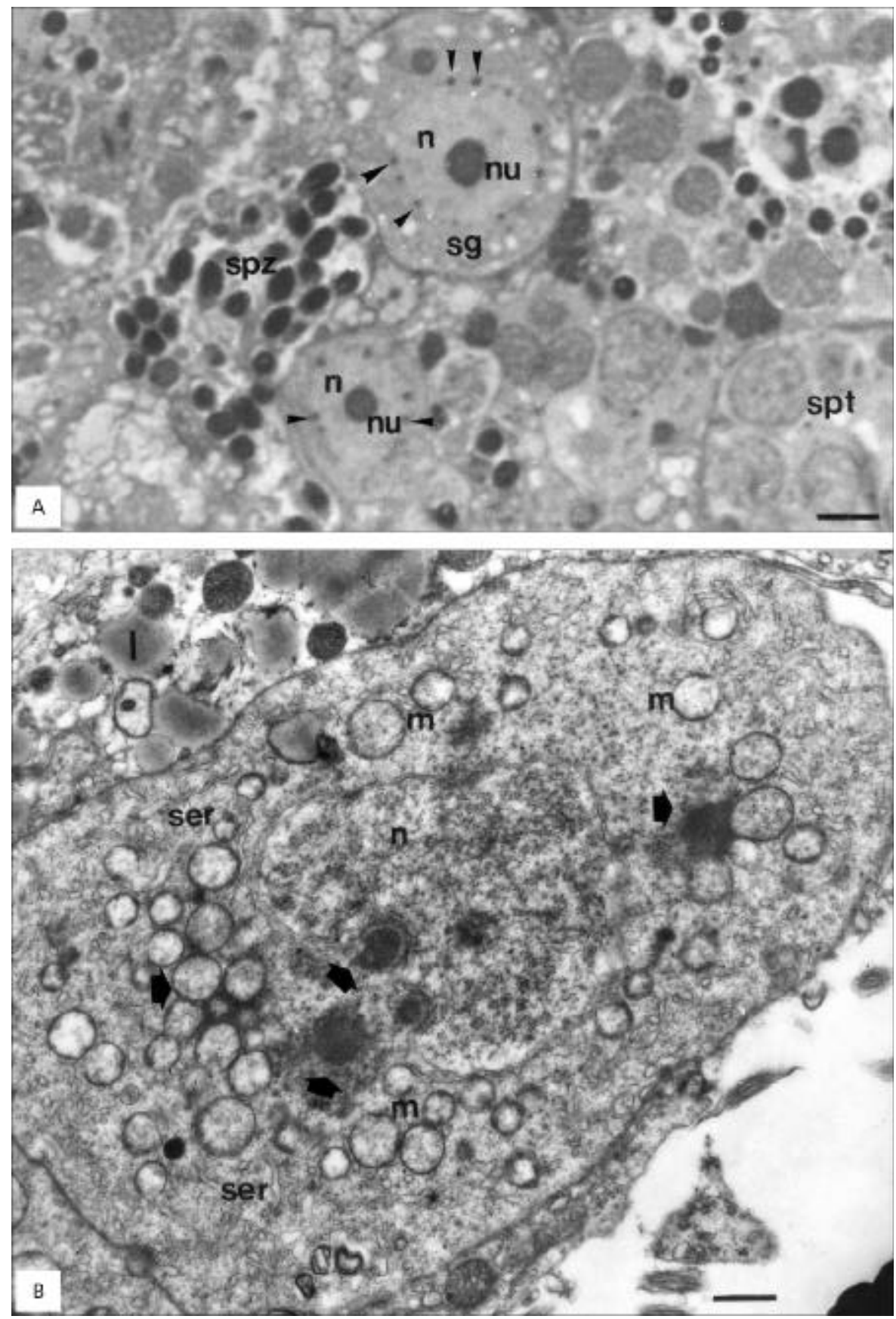

Fig. 2 - A. Light microscopy (LM) showing nuage (arrow's head) in spermatogonia (sg). n, nucleus; nu, nucleoli; spt, spermatids; spz, spermatozoa; Bars $=0.1 \mu \mathrm{m}$. B. TEM of a spermatogonium. Arrows point to nuage lodged in depressions of the nuclear envelope and dispersed in the cytoplasm, which may be associated with mitochondria; 1 , lipid granules of a cystic cell; $\mathrm{m}=$ mitochondria; ser $=$ smooth endoplasmic reticule; Bars $=1 \mu \mathrm{m}$. 
According to Clérot (1979), the association with mitochondria might mean a role in this organelle replication, since these germ cells increase the mitochondria number in the cytoplasm. Nevertheless, although it is known that mitochondria import proteins from cytoplasm (Alberts et al., 1989), nothing is known about nucleic acid import during their replication.

According to Reunov et al. (2000), during spermatogenesis of the sea urchin Anthocidaris crassispina, modified mitochondria associates with nuclear nuage and release some of their content into the cytoplasm, suggesting that the germ plasm is supplemented by the mitochondrial genome.

Therefore, the nuage-mitochondria association seems to have an important role in oocyte development, but it is unlikely to have the same in spermatogonia since their cytoplasm is lost during spermatogenesis, and even spermatogonial mitochondrial derivates are left out of the oocyte in fertilization.

During spermatogenesis the nucleus is expected to have few opportunities for gene expression. Therefore, it is possible that the material extruded is long-lasting RNA to be used during gamete maturation. This may result from the transcription of genes responsible for the synthesis of cell division regulators, since these spermatogonia intensely divide mitotically before starting meiosis, and the meiotic division occurs without an interphase. If no new RNA is produced after the spermatogonia proliferation starts, the longlasting RNA, entering the cytoplasm in the spermatogonia, may even have some function during spermiogenesis.

In females a new elimination of nuclear material took place during the primary growth stage of the oocyte (Fig. 1B). At a certain stage of this process, nuage dispersed in an area surrounded by mitochondria (Fig. 1C). In some follicles this material was very electrondense, and after mitochondrial association became thread-like (Fig. 3A), occupying a great extension of the cytoplasm (Cruz-Landim \& Cruz-Höfling, 1979). In a more advanced dispersion stage, many annulated lamellae appeared in the cytoplasm and could be seen associated with this electrondense material.

The extrusion of material from the micronucleoli to the cytoplasm produced within the nuclear matrix vacuoles visible under light (Fig. 3B) and by transmission electron microscopy (Fig. 3C). After a while, the vacuoles seemed to collapse, leaving only very electrondense membranous residues (Figs. $1 \mathrm{C}$ and $3 \mathrm{D}$ ).

Therefore, material transferred later, in the oocyte, is thought to constitute germ plasm, which according to Eddy (1975) is constituted mainly of ribonucleoproteins with a ribosomic function, but more recent data point to the presence of long-lasting mRNA in its composition (Alberts et al., 1989).

In P. mesopotamicus it is seen, in initial phases of oocyte I maturation, being produced in specific chromosome regions and accumulating in the micronucleoli, before passing throughout the nuclear pore complexes to the cytoplasm.

In conclusion, whereas the female germ cells presented two moments of nuclear material extrusion (in the oogonia and in the perinucleolar phase of the oocyte), in males the extrusion was present only in spermatogonia. In all cases the material is probably constituted of ribonucleoproteins from ribosomes, or mRNA. It is possible that the nuclear material reaching the cytoplasm in oogonia and in spermatogonia are similar and supply information about the final destiny and function of these cells, while material transferred during oocyte perinucleolar phase enter into the germ plasm constitution. 

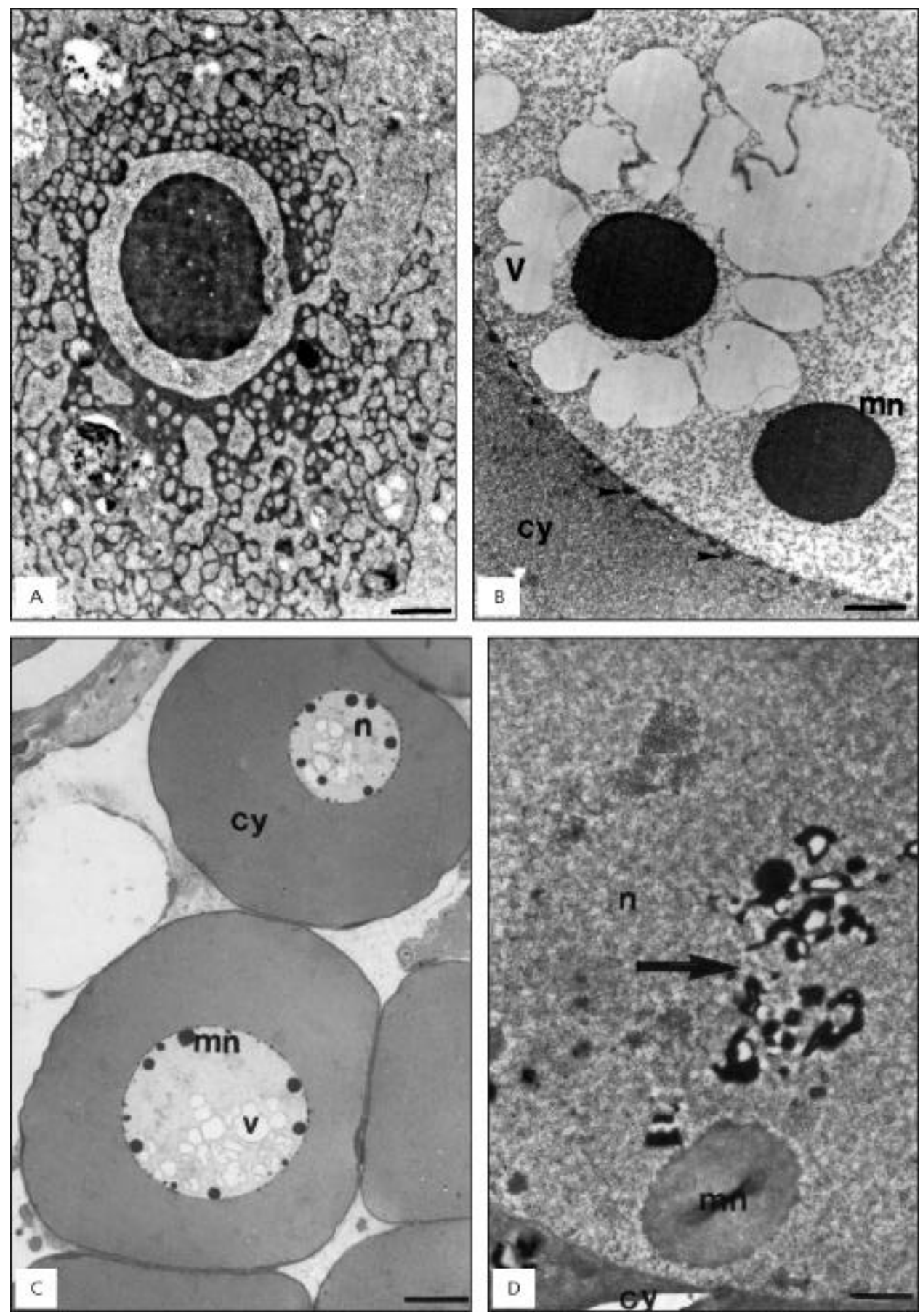

Fig. 3 - A. Detail of the perinucleolar oocyte, showing thread-like electrondense material (nuage) dispersion. Bars $=0.5 \mathrm{~m}$. B. LM of oocytes in perinucleolar stage, showing vesicles (v) inside the nucleus $(\mathrm{n})$. The micronucleoli (mn) are very evident. cy, oocyte's cytoplasm; Bars $=0.1 \mu \mathrm{m}$. C. Oocyte nucleus in perinucleolar stage, showing a micronucleolus (mn) surrounded by vesicles (v). cy $=$ cytoplasm of an oocyte; Bars $=3 \mu \mathrm{m}$. D. Detail of a nucleus (n) in a more advanced perinucleolar stage, showing lamellar structures (arrow). cy, oocyte cytoplasm, mn, micronucleolus. Bars $=1 \mu \mathrm{m}$. 


\section{REFERENCES}

ABDALlA, F. C. \& CRUZ-LANDIM, C., 2003, Some histological and ultra-structural aspects of the oogenesis of Piaractus mesopotamicus Holmberg, 1887 (Teleostei). Braz. J. Morphol. Sci., 20: 3-10.

AGOSTINHO, A. A., 1985, Estrutura da população, idade, crescimento e reprodução de Rhinelepsis aspera (Agassig, 1829) (Osteichthlyes, Loricaridae) do rio Paranapanema, $P R$. Tese de doutorado, Universidade Federal de São Carlos, UFSCar, São Carlos, SP, 229p.

ALBERTS, B., BRAY, D., LEWIS, J., RAFF, M., ROBERTS, K. \& WATSON, J. D., 1989, Molecular biology of the cell. 2. ed. Garland Publishing, Inc., New York, USA, pp. 856-876.

BRUSLÉ, S., 1980, Fine structure of early previtellogenic oocytes in Mugil (Liza) auratus Risso, 1810 (Teleostei, Mugilidae). Cell Tissue Res., 207: 123-134.

CLÉROT, J. C., 1976, Les groupements mitocondriaux des cellules germinales des poisons téleostéens cyprinids. I. Étude ultrasctructurale. J. Ultrastruct. Res., 54: 461-475.

CLÉROT, J. C., 1979, Les groupements mitochondriaux des cellules germinales des poissons téléostééns Cyprinidés. Exp. Cell Res., 120: 237-244.

CRUZ-HÖFLING, M. A. \& CRUZ-LANDIM, C., 1990, The ultrastructure of the developmental stages of the oocytes of Astyanax bimaculatus (Teleostei: Characidae). Zool. Jb. Anat., 120: 163-181.

CRUZ-LANDIM, C. \& CRUZ-HÖFLING, M. A., 1979, Comportamento dos nucléolos e mitocôndrias durante a ovogênese de peixes teleósteos de água doce. Acta Amazonica, 9: 723-728.

DADZIE, S., 1969, Spermatogenesis and the stages of maturation in the male cichlid fish Tilapia mossambica. J. Zool., 159: 399-403.

DOHMEN, M. R., 1985, "Nuage" material and the origin of dense-core vesicles in oocytes of Nassarius reticulates (Mollusca, Gastropoda). Int. J. Invert. Reprod. Develop., 8: $117-125$

DROLLER, M. J. \& ROTH, T. F., 1966, An electron microscope study of yolk formation during oogenesis in Lebistes reticulates uppyi. Cell Biol., 28: 209-232.

EDDY, E. M., 1975, Germ plasm and the differentiation of the germ cell line. Rev. Cytol., 43: 229-280.

ESPER, H., 1965, Studies of the nucleolar vacuole in the oogenesis of Arbacia punctulata. Exp. Cell. Res., 38: 85.

GRIER, H. J., 1981, Cellular organization of the testis and spermatogenesis in fishes. Amer. Zool., 21: 345-357.

GUIMARÃES, A. C. D. \& QUAGIO-GRASSIOTTO, I., 2001, Ultrastructural aspects of oogenesis and oocyte primary growth in Serrasalmus spilopleura (Teleostei, Characiformes, Characidae). Tissue \& Cell, 33: 241-248.

GUIMARÃES, A. C. D. \& QUAGIO-GRASSIOTTO, I., 2002, The ultrastructural aspects of vitellogenesis or oocyte secondary growth in Serrasalmus spilopleura (Teleostei, Characiformes, Serrasalminae). J. Submicrosc. Cytol. Pathol., 34: 199-206.
KATO, K., 1968, Cytochemistry and fine structure of elimination chromatin in Dytiscidae. Exptl. Cell Res., 52: 507-522.

KESSEL, R. G., 1968, Electron microscope studies on the origin and maturation of yolk in oocytes of the Tunicate Ciona intestinalis. Z. Zellforsch, 71: 525-544.

LEWIS, J. C. \& MCMILLAN, D. B., 1965, The development of the ovary of the sea lamprey (Petromison marinus L.). J. Morphol., 117: 425.

REUNOV, A., ISAEVA, V., AU, D. \& WU, R., 2000, Nuage constituents arising from mitochondria: is it possible? Dev. Growth Differ., 42: 139-143.

ROMAGOSA, E., 1991, Mudanças morfológicas (microscopia de luz e eletrônica) das gônadas de pacu, Piaractus mesopotamicus (Holmberg, 1887) durante o ciclo reprodutivo, em condições de confinamento. Dissertação de Mestrado, IBRC, UNESP, Rio Claro, SP, 177p.

ROMAGOSA, E., NARAHARA, M. Y., TALMELLI, E. A. \& BRAGA, F. M. S., 1993, Mudanças morfológicas dos testículos de pacu, Piaractus mesopotamicus (Holmberg, 1887), em condições de confinamento. Rev. UNIMAR, 15(Suppl.): 1-17.

ROMAGOSA, E., NARAHARA, M. Y., AIROSA, L. M. S., BORELLA, M. I. \& FENERICH-VERANI, N., 2000, Reproductive cycle of male matrinxã, Brycon cephalus (Günther, 1869) (Teleostei: Characidae). Braz. J. Morphol., 17: 101-105.

RUSSEL, L. \& FRANK, B., 1978, Ultrastructural characterization of nuage in spermatocytes of the rat testes. Anat. Rec., 190: 79.

SELMAN, K. \& WALLACE, R. A., 1983, Oogenesis in Fundulus heteroclitus. III. Vitellogenesis. J. Exp. Zool., 226: 441-457.

SHRESTHA, T. K. \& KHANNA, S. S., 1978, Seasonal changes in the testes of a hill stream teleost, Garra gotyla (Gray). Acta Anat., 100: 210-220.

SILVA, M., 1987, Morfologia ultra-estrutural do testículo, cinética da espermatogênese e barreira hemo-testicular da tilápia do Nilo, Oreochromis niloticus (Peixe, Ciclídeo). Tese de Doutorado, Universidade Federal de Minas Gerais, Belo Horizonte, MG, 164p.

TYLER C. R. \& SUMPTER, J. P., 1996, Oocyte growth and development in teleosts. Rev. Fish. Biol. Fresheries, 6: 287-318.

VAN GANSEN, P. V. \& SHRAM, A., 1968, Ultrastructure et cytochimie ultrastructurale de la vésicule germinative et du cytoplasme périnucléaire de l'oocyte mûr de Xenopus laevis. J. Embryol. Exp. Morphol., 20: 375.

YAMAMOTO, K., 1956, Studies on the formation of fish eggs. I Annual cycle in the development of ovarian eggs in the flounder, Liopsetta obscura. J. Fac. Sci. Hokkaido Univ. Ser. VI Zool., 12: 362-373. 